\title{
Effect of Silver Nanoparticles on Growth of Eukaryotic Green Algae
}

\author{
Anjali Dash ${ }^{1 *}$, Anand P. Singh ${ }^{2}, \quad$ Bansh R. Chaudhary ${ }^{2}$, Sunil K. Singh ${ }^{1}, \quad$ Debabrata Dash ${ }^{1}$
}

(Received 10 May 2012; accepted 18 September 2012; published online 25 September 2012.)

\begin{abstract}
Silver nanoparticles, endowed with powerful antimicrobial property, are the most widely used nanomaterial in consumer products, with associated risk of their easy access to environment and freshwater ecosystems by surface runoff. Although toxic effects of nanosilver on bacterial, fungal and mammalian cells have been documented, its impact on algal growth remains unknown. Pithophora oedogonia and Chara vulgaris are predominant members of photosynthetic eukaryotic algae, which form major component of global aquatic ecosystem. Here we report for the first time that nanosilver has significant adverse effects on growth and morphology of these filamentous green algae in a dose-dependent manner. Exposure of algal thalli to increasing concentrations of silver nanoparticles resulted in progressive depletion in algal chlorophyll content, chromosome instability and mitotic disturbance, associated with morphological malformations in algal filaments. SEM micrographs revealed dramatic alterations in cell wall in nanoparticle-treated algae, characterized with cell wall rupture and degradation in Pithophora. Although these observations underscore severe deleterious effects of nanosilver on aquatic environment, the information can also be exploited as a bioengineering strategy to control unwanted and persistent growth of noxious algal weeds that clog the municipal water supply and water channels and produce fouling of water bodies.
\end{abstract}

Keywords: Silver nanoparticles; Green algae; Algal growth; Photosynthetic pigment; Nanotoxicity

Citation: Anjali Dash, Anand P. Singh, Bansh R. Chaudhary, Sunil K. Singh and Debabrata Dash, "Effect of Silver Nanoparticles on Growth of Eukaryotic Green Algae", Nano-Micro Lett. 4 (3), 158-165 (2012). http:// dx.doi.org/10.3786/nml.v4i3.p158-165

\section{Introduction}

Metal particles in nanometer range are endowed with unique optical, electrical and magnetic properties. Increasing number of commercial products ranging from cosmetics to medicine incorporate manufactured nanomaterials, which can be accidentally or incidentally released to the environment $[1,2]$. Concern over harmful effects of such nanoparticles has stimulated the advent of nanotoxicology as a significant research discipline. Majority of such studies, however, have focused on mammalian cytotoxicity or the impact of nanomaterials on bacteria, with relatively few insights on their toxic effects on plants [3].
The inherent antibacterial properties of silver nanoparticles (AgNPs) [4-9] have dramatically augmented their commercial use in consumer products such as food packaging, odour-resistant textiles, household appliances and medical devices including wound dressings ('Band Aids'), thus raising the likelihood of their access into ambient aquatic systems. Of late concerns have mounted over their potential to adversely affect beneficial bacteria in the environment, especially in soil and water. Although toxic effects of nanosilver on bacterial, fungal and mammalian cells have been well documented [9-11], its impact on the growth and biology of algae remains a 'black box'. Algae are an important component of our environment and ecosystem. Their

\footnotetext{
${ }^{1}$ Department of Biochemistry, Institute of Medical Sciences, Banaras Hindu University, Varanasi-221005, India

${ }^{2}$ Centre of Advanced Study in Botany, Banaras Hindu University, Varanasi-221005, India

*Corresponding author. E-mail: ddass@sify.com
} 
important benefits include uses as biofertilizer, biofuel, pollution control agent (algae bioreactors), stabilizer of casein and source of nutrition (B complex vitamins and minerals). Only a few studies to evaluate the effect of AgNPs on unicellular microalgal growth, such as Chlamydomonas [12], and marine diatom Thalassiosira [13], are on record, despite great value attached to such information in the operation planning and control of wastewater treatment systems. Scanty preliminary reports also exist appraising the toxic effects of $\mathrm{CuO}$ nanoparticles on Chlamydomonas [14], and of nanoparticulate $\mathrm{ZnO}$ on Pseudokirchneriella [15]. In view of above, the present investigation was aimed at evaluating the impact of nanosilver, the most abundantly used nanomaterial in consumer products with potential access to aquatic water bodies, on photoautotrophic growth of luxuriantly growing filamentous green algae Pithophora oedogonia and Chara vulgaris, which have remained so far unexplored.

\section{Experimental section}

\section{Collection and cultivation of algae}

Algal materials collected from aquatic bodies and identified as Pithophora oedogonia (Mont.) Wittrock and Chara vulgaris Linn. were washed thoroughly under running water to remove attached epiphytes and the associated debris. Cultivation was carried out in the soil-water biphasic medium [16], as well as Bold's Basal inorganic nutrient solution [17], supplemented with $10 \%$ soil extract as organic source. Equal amounts of sample $(0.5 \mathrm{~g})$ were taken in tubes containing culture medium and incubated in growth chamber maintained at $25 \pm 1^{\circ} \mathrm{C}$ with an illumination of 2 Klux from coolwhite fluorescent tube lights for $16 \mathrm{~h}$ per day.

\section{Synthesis of silver nanoparticles}

Silver nanoparticles were synthesized as described earlier $[9,11,18]$. Solution of $\mathrm{AgNO}_{3}(0.01 \mathrm{M})$ was prepared by dissolving $0.017 \mathrm{~g}$ salt in $100 \mathrm{ml}$ deionized water. During the process, additives like ammonia (30\%) were added dropwise, so that silver ions formed a stable soluble complex. A blend of reducing agents, Dglucose and hydrazine, was used during the synthesis of nanoparticles. Blending was essential to control the rate of reduction, so that an optimum rate of AgNPs production was achieved. A higher reducing rate has been shown to form clusters of silver nanoparticles with reduced stability [19]. About $110 \mathrm{ml}$ of blend of reducing agents (at a concentration of $0.01 \mathrm{M}$ ) was added to $100 \mathrm{ml}$ silver nitrate stock solution $(0.01 \mathrm{M})$ with continuous stirring. This ensured complete reduction of silver ions to form silver nanoparticles at $0.005 \mathrm{M}$ concentration in aqueous medium. The $\mathrm{pH}$ of nanoparticles thus formed was maintained at 7.4 with citric acid (1 $\mathrm{M})$. The brown solution of Ag nanoparticles was stored in closed glass vials under ambient conditions for future experiments.

\section{Characterization of AgNPs}

To verify reduction of silver ions, solution was scanned against water in the range from 200 to 600 $\mathrm{nm}$ in spectrophotometer (Pharmacia Biotech) using quartz cuvettes. Size and morphology of nanoparticles were analyzed with a transmission electron microscope (JEOL) and UV-Vis spectrophotometer (Pharmacia Biotech). Sample was prepared by placing a drop of silver nanoparticles on carbon-coated copper grid and subsequently drying in air, before transferring it to the microscope operated at an accelerated voltage of $120 \mathrm{kV}$. Stability of nanoparticles was examined by exposing them to the ambient conditions for four weeks, followed by centrifugation (Sigma) at $15000 \mathrm{~g}$ for $15 \mathrm{~min}$ at RT to rule out the formation of precipitate with time. The colour and $\mathrm{pH}$ of the solution were also checked at regular intervals, which hardly showed any change.

\section{Photosynthetic pigment measurement}

Freshly grown algae ( $0.5 \mathrm{~g}$ each) were incubated with varying concentrations of silver nanoparticles (in $20 \mathrm{ml}$ Bold's Basal Medium) at $22 \pm 1^{\circ} \mathrm{C}$ under diffuse fluorescent tube light illumination with day/night rhythm of $16 \mathrm{~h} / 8 \mathrm{~h}$. After 10 days incubation, chlorophyll was extracted from the samples in $10 \mathrm{ml}$ acetone (80\%) for overnight at $4^{\circ} \mathrm{C}$, followed by centrifugation at $5000 \mathrm{~g}$ for $10 \mathrm{~min}$. Supernatant was collected and absorbance was measured at $652 \mathrm{~nm}$ with UV-Vis spectrophotometer. Total chlorophyll content was calculated according to the following formula [20]:

Total chlorophyll $(\mathrm{mg} / \mathrm{gm}$ of plant material $)=\left(\mathrm{OD}_{652}\right.$ $\times 1000 / 34.5) \times(V / 1000 \times W)$, where $V=$ Volume of the chlorophyll extracted (in $\mathrm{ml}$ ), and $W=$ Weight of the plant material (in gm)

After 10 days, the total chlorophyll content was determined. The data were subjected to means and standard deviations calculated for each treatment and significant differences between control and exposed algae were determined by analysis of variance (ANOVA) where value less than 0.05 was considered to be significant.

\section{Nuclear cytology}

Filaments of $P$. oedogonia and $C$. vulgaris were fixed with paraformaldehyde (4\%) at RT and observed under phase contrast microscope (Leica, model DM LB2). AgNP-treated algae were studied under light microscope for analysis of chromosomal behaviour during mi- 
tosis. After treatment with AgNPs algal materials were thoroughly washed and fixed in Carnoy's fluid (3 parts glacial acetic acid and 1 part absolute alcohol). Microscopic slides were prepared following iron-alum acetocarmine squash technique [21].

\section{SEM analysis}

For SEM, algal filaments grown in nutrient-enriched BBM, with or without silver nanoparticles pretreatment, were fixed in Karnovsky fixative followed by postfixation in osmium tetroxide ( $1 \%$ solution). The materials were dehydrated in ascending grades of acetone and critical point dried, followed by mounting on an aluminium stub with adhesive tape and sputter-coated with colloidal gold. Specimens were viewed under a Leo $435 \mathrm{VP}$ scanning electron microscope at an operating voltage of $15 \mathrm{kV}$.

\section{Results and discussion}

Silver nanoparticles were characterized by transmission electron microscopy. Particles were found to be within the size range between 10 to $15 \mathrm{~nm}$ (Fig. 1). Se- lected area electron diffraction (SAED) pattern from these particles matched the crystallographic planes of the face centered cubic (fcc) silver particles (Fig. 1(c)). Nanoparticles were found to be well dispersed with narrow particle size distribution (Fig. 1(d)). UV-visible absorption spectra showed the reduction of silver ions into the AgNPs under ambient conditions (Fig. 1(e)). The inset shows the colour changes before (1), and after the process of reduction (2). The silver nitrate solution exhibited maximum absorbance at $300 \mathrm{~nm}$, which gradually underwent red shift with appearance of a sharp peak at $410 \mathrm{~nm}$ which can be attributed to a narrow size distribution of the particles formed in the solution.

Effect of AgNPs on pigment content as a measure of algal growth and photosynthetic efficiency was investigated. Content of total chlorophyll in both algal species exhibited significant $(\mathrm{P}<0.05)$ reduction following exposure to AgNPs in contrast to the control (untreated) values (Fig. 2). The decrease was more pronounced in $C$. vulgaris than in $P$. oedogonia, which could be attributed to harder cottony assemblage of filaments in the latter taxon, resisting interaction with silver nanoparticles.
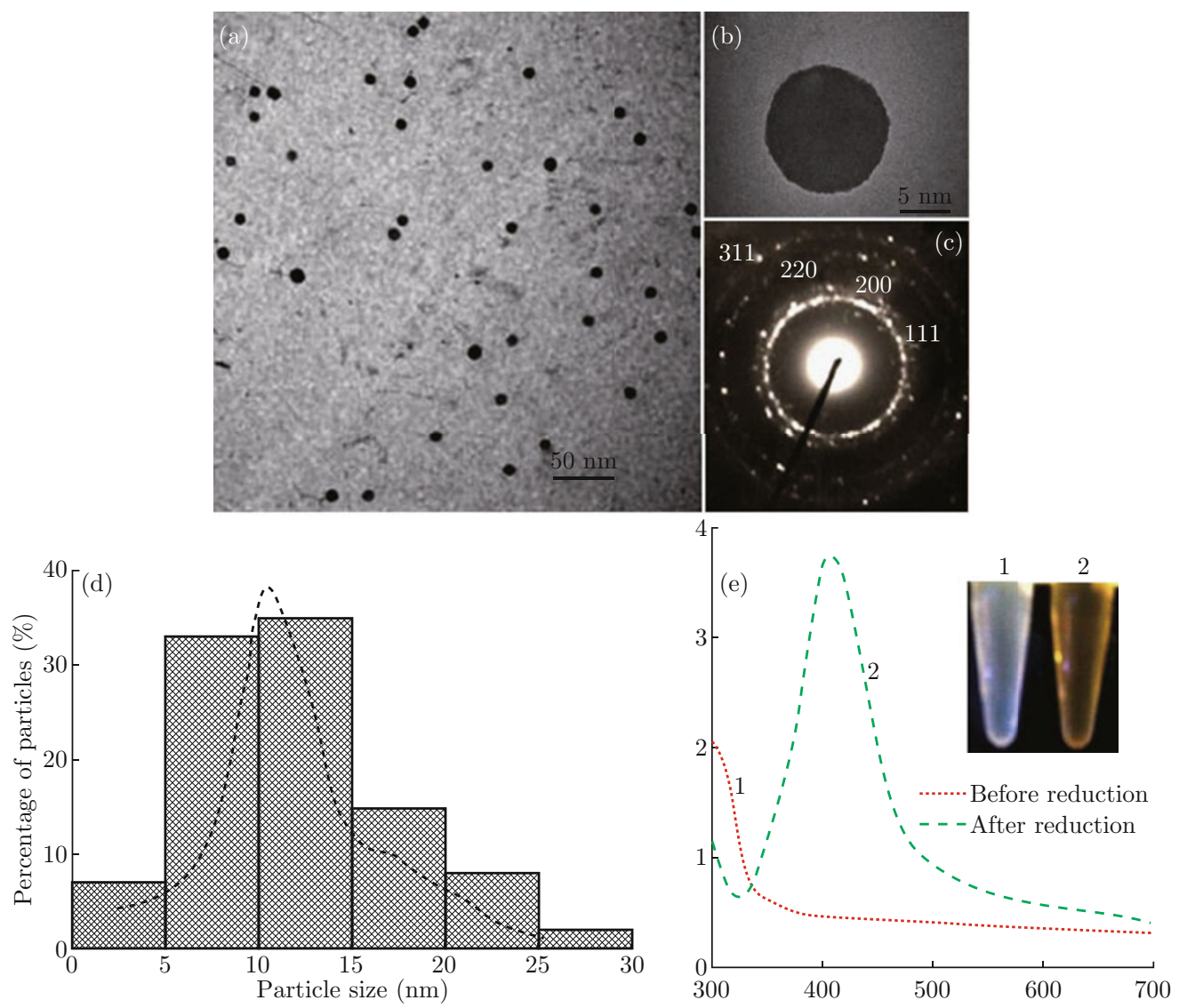

Fig. 1 Characterization of AgNPs. (a) AgNPs showing spherical, mono-dispersed particles (scale bar, $50 \mathrm{~nm}$ ); (b) Amplified TEM image shows one single particle of silver (scale bar, $5 \mathrm{~nm}$ ); (c) Electron diffraction pattern of nanoparticles showing various crystallographic plans; (d) Particle size distribution showing preponderance of particles in the size range of 10-15 nm; (e) Optical spectra of silver before (1) and after reduction (2). Inset shows the corresponding change in color. 

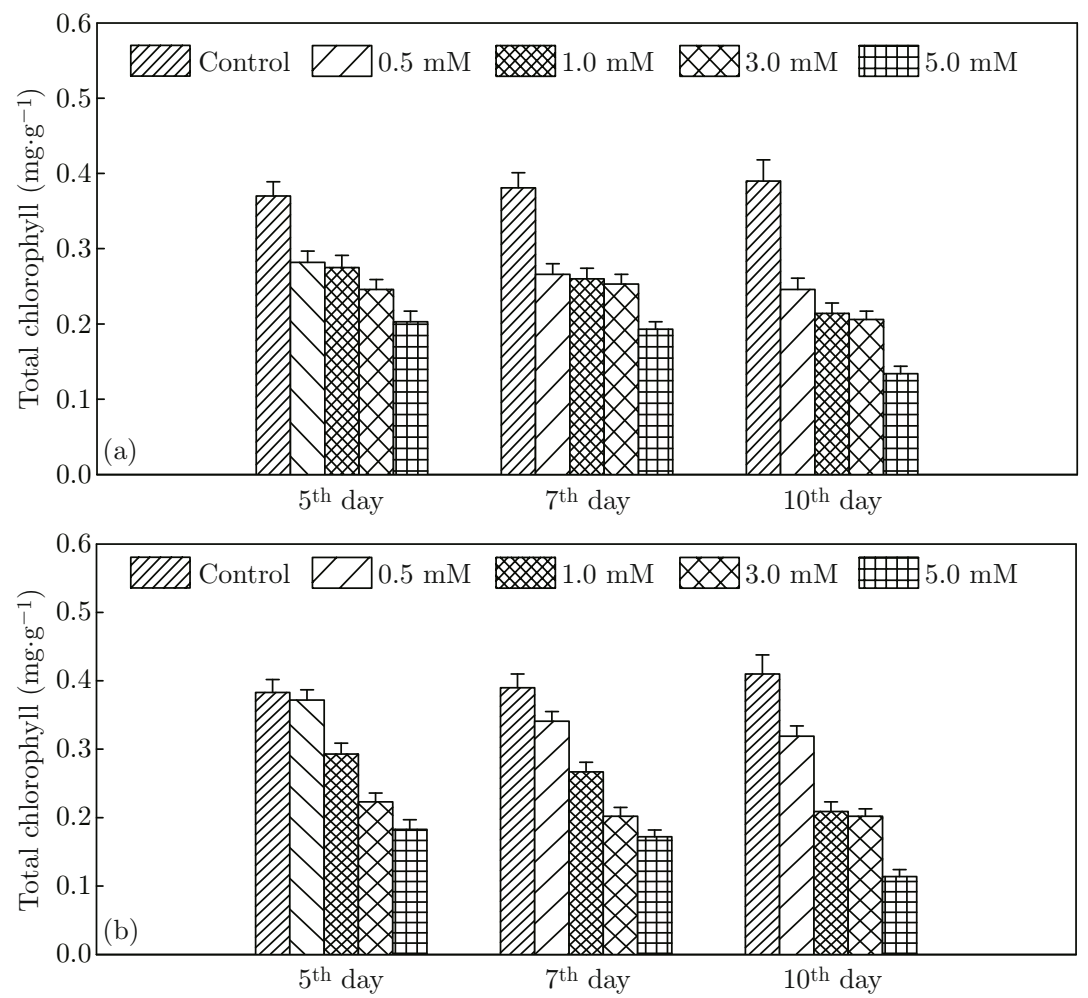

Fig. 2 Total chlorophyll content in P. oedogonia (a) and C. vulgaris (b) on $5^{\text {th }}, 7^{\text {th }}$ and $10^{\text {th }}$ day of exposure to different concentrations of AgNPs as indicated.

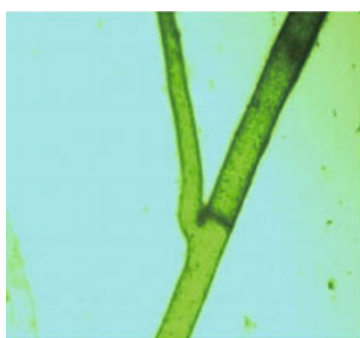

(a)

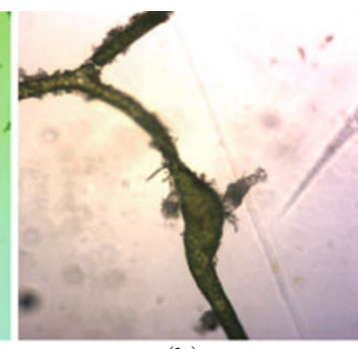

(b)

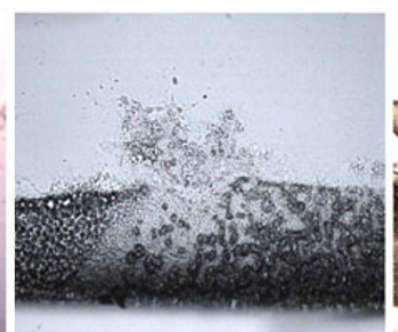

(c)

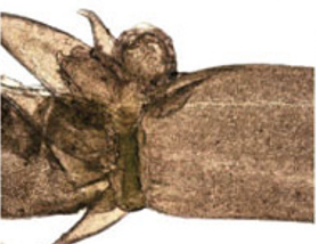

(d)

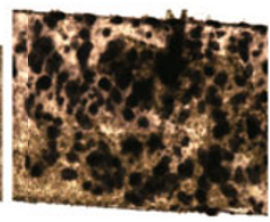

(e)

Fig. 3 Light microscopy of P. oedogonia and C. vulgaris. (a) Control filament of P. oedogonia (100×), (b) Pithophora filament treated with AgNPs (0.9 mM) for 20 days showing bulbous and swollen morphology (100×), (c) Pithophora filament treated with $\mathrm{AgNP}(1.5 \mathrm{mM})$ for 10 days showing ruptured cell wall and chlorophyll oozing out (400×), (d) Control thallus of $C$. vulgaris $(10 \times)$, (e) AgNPs-treated thallus of C. vulgaris showing adsorption of AgNP aggregates on to the algal surface $(10 \times)$.

AgNPs affected survival and morphological characteristics of these filamentous algae in a manner dependent on dose and duration of exposure to nanoparticles. On $5^{\text {th }}$ day of exposure to AgNPs $(1.5 \mathrm{mM})$ algal filaments turned yellowish-green in color in comparison to the respective controls. AgNP-treated Pithophora exhibited regional bulging of filaments with greater accumulation of chlorophyll at apical or middle portions as darker segments (Fig. 3(b)), while uniform distribution of chlorophyll was witnessed in control materials (Fig. 3(a)). When cultures of Pithophora were allowed to remain exposed to AgNPs (0.9 mM) for 30 days or more, fresh tiny filaments were found to emerge from algae (not shown).
Higher concentration and longer duration of exposure to the nanoparticles extensively damaged chloroplasts leading to their granulation and contraction in algal cells. Some filaments of Pithophora also exhibited bulged cells with contracted chloroplasts. As AgNP concentration increased to $1.5 \mathrm{mM}$ chloroplast became fragmented and subsequently got disintegrated. Occasionally, cell wall became thin and ruptured, leading to leakage of chlorophyll from the filaments (Fig. 3(c)). The untreated Chara plant remained green and flourished well in the culture medium under laboratory culture conditions. But, when C. vulgaris was coincubated with nanosilver for 5-10 days under culture conditions, the green colour of thalli turned yellow with progressive 
loss of chlorophyll. Upon microscopic examination, aggregates of nanoparticles were found adsorbed onto the surface of algal filaments as black shower (Fig. 3(e)), the extent of which depended on concentration and duration of AgNP treatments.

Effect of AgNPs on cell division and chromosome behavior in $P$. oedogonia $(2 \mathrm{n}=24)$ and $C$. vulgaris $(2 \mathrm{n}=14)$ was subsequently investigated. Algae treated with high concentrations of nanoparticles $(1.5 \mathrm{mM}$ and above) did not yield enough metaphases with only few cells progressing into mitosis, suggestive of mitostatic nature of the nanoparticles. Cytological abnormalities like unusual condensation, unequal separation and clumping of chromosomes were apparent in AgNP-treated filaments of $P$. oedogonia and C. vulgaris (Fig. 4). Besides, metaphase was found to be disturbed in many cells in $C$. vulgaris. These results

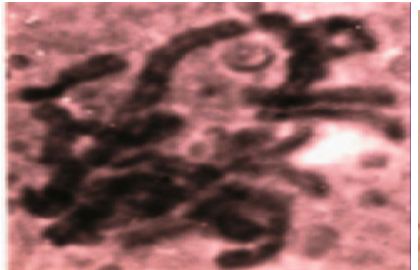

(a)

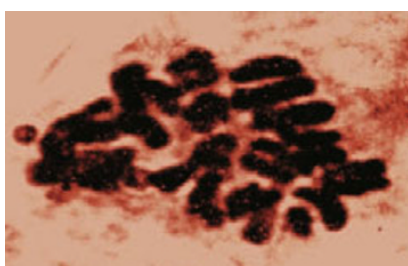

(b)

conform to the earlier findings on the effect of $\mathrm{Ag}$ NPs on root tip cells of Allium cepa [22] and human cells [23]. Longer exposure (for 5 to 10 days) to AgNPs enhanced the magnitude of chromosome anomalies with no obvious recovery process, clearly indicative of heavy genetic damage and/or total imbalance of the nuclear material induced by nanosilver during division.

Scanning electron microscopy of Pithophora oedogonia exposed to AgNPs (1.5 mM) for 10 days revealed dramatic alterations in cell wall, which included cell surface disruption, shrinkage and extensive surface irregularity reflective of wall rupture and degradation (Fig. 5(a) and 5(b)). Surface of Chara filaments exposed to nanosilver appeared to be smoothened with localized dark aggregates of nanoparticles on thalli (Fig. 5(d)).

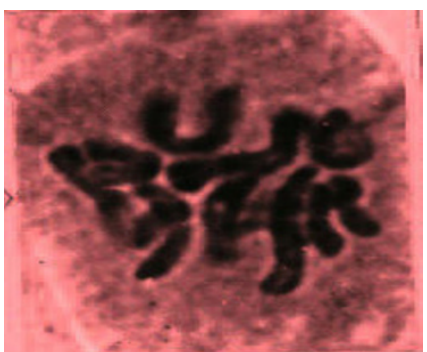

(c)

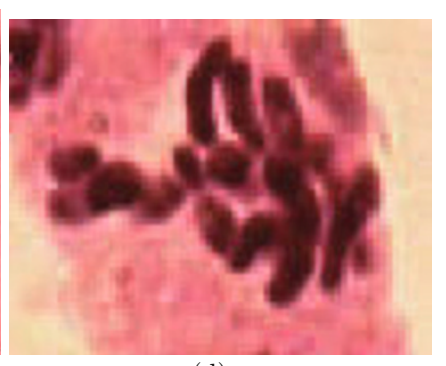

(d)

Fig. 4 Metaphase squashes of $P$. oedogonia $(2 \mathrm{n}=24)(1000 \times)$ showing (a) normal metaphase, and (b) metaphase under the influence of AgNPs $(0.9 \mathrm{mM})$ for 5 days displaying condensation and clumping of chromosomes. Metaphase of C. vulgaris $(2 \mathrm{n}=14)(1000 \times)$ showing $(\mathrm{c})$ control/normal metaphase, and $(\mathrm{d})$ metaphase nucleus under the influence of AgNPs $(0.9 \mathrm{mM})$ for 5 days displaying disturbed phase.
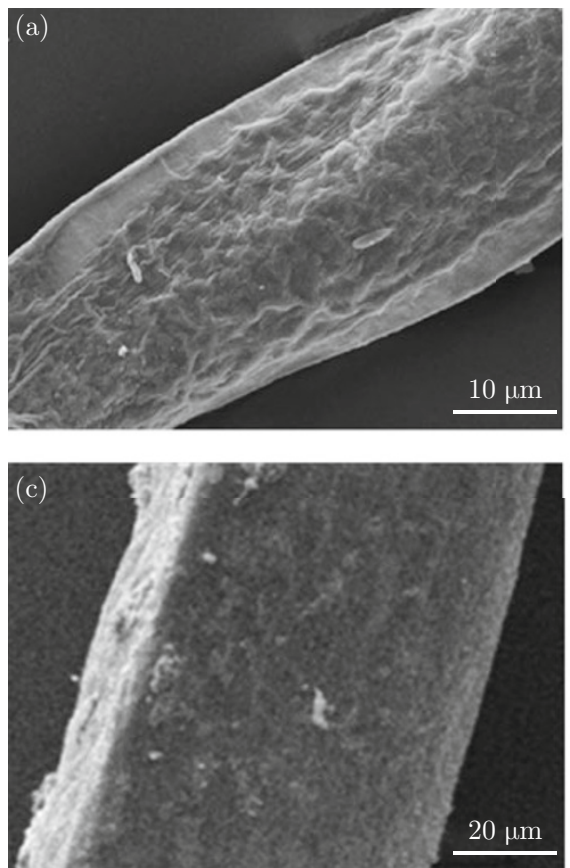
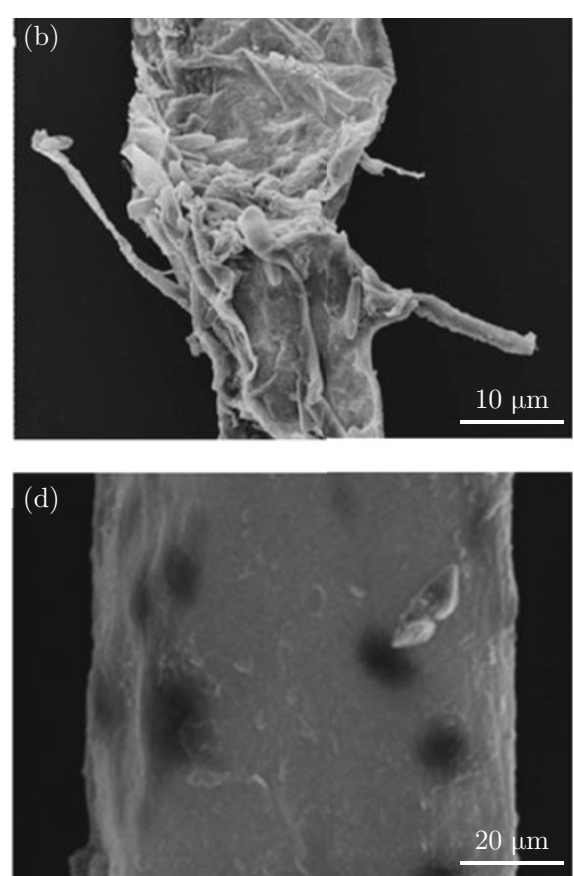

Fig. 5 SEM images of filaments of P. oedogonia (a) and (b); as well as Chara vulgaris (c) and (d). The sample shown in (a) and (c) are images of controlled (untreated) filaments; (b) and (d) are for AgNP-treated filaments. 
Unique properties associated with nanomaterials have opened up opportunities for their industrial and commercial applications, with growing number of consumer products exploiting the benefits. It has become increasingly obvious that nanoparticles can easily enter the aquatic environment during the course of their production, use or disposal. Nanomaterials have the potential to interact with and even drastically affect the live stocks (both plants and animals) in the environment [24]. Silver nanoparticles, endowed with powerful antimicrobial property, are the most widely used nanomaterial in consumer products, but little is known about their effect on environment. Particles of nanosilver can find ready access to freshwater ecosystems by surface runoff. Pithophora oedogonia and Chara vulgaris are predominant members of photosynthetic eukaryotic algae, which form major component of aquatic ecosystem. In this communication, we report for the first time that nanosilver has extensive adverse effects on growth and morphology of these filamentous green algae in a dosedependent manner. Discoloration of filaments due to chloroplast contraction followed by disintegration, regional bulging of filaments, thinning and disruption of the cell wall permitting exclusion of the chlorophyll pigments, adsorption of AgNPs on cell surface and organellar membranes, mitostatic effect, induction of chromosomal anomalies and irreversible genetic damage were significant detrimental effects of nanosilver recorded in test algae.

Cell wall constitutes a primary site for interaction as well as serves as a barrier for the entrance of nanosilver into algal cells. Major components of cell wall are carbohydrates (cellulose), linked to form a multisheath rigid complex and proteins (usually glycoproteins and polysaccharides). Nature of interaction between Pithophora or Chara and nanosilver may vary due to differences in the structure of cell walls. Bioadsorption of heavy metal particles to algae is dependent on surface charge on these particles [25]. Sieving property of algal cell walls is determined by pore sizes ranging from 5 to $20 \mathrm{~nm}$ [26-28], which span through thickness of the walls. Thus, only NPs smaller than $20 \mathrm{~nm}$ are expected to reach cell membrane. Once cell wall is penetrated endocytotic passage through plasma membrane may be possible [29]. Nanosilver has been shown to interact with proteins [18], and induce posttranslational modifications [30], modulating cell physiology. Possible release of $\mathrm{Ag}^{+}$from oxidative dissolution of nanosilver can also adversely affect physiology of a wide variety of organisms including bacteria and algae $[12,13]$. Thus, reactivity of nanosilver against algal components can adversely impact algal photosynthetic enzymes, as evidenced from temporal decrease in total chlorophyll content, nuclear division leading to chromosomal aberrations and damage to the cell wall.

In a recent study conducted by Aruoja et al. [31] nanosized particles were found to cover algal surfaces to a greater extent than the bulk particles. Particle adhesion may lead to physical consequences, such as disruption of cell membrane or reduction in cellular nutrient uptake. Oxidative stress as well as impaired ATP synthesis have been suggested as possible mechanisms for antimicrobial effect of nanoparticles [32,33]. Generation of photocatalytical reactive oxygen species (ROS) is also known to contribute to cytotoxicity of copper NPs against unicellular green alga Chlamydomonas reinhardtii [14]. In the present study, however, toxicity of AgNPs was not affected by changes in light intensity. This is in agreement with the observed antibacterial activity of photosensitive nanomaterials under both dark and light conditions [34], suggestive of mechanisms other than photocatalytical ROS contributing to cytotoxicity.

Alteration in composition of an aquatic community as a result of toxic stress has been reported to affect structure and functioning of the entire ecosystem [35]. The photosynthetic green algae, both unicellular and multicellular, are known to be sensitive to chemicals, and have been considered indicators of bioactivity of industrial waste [36]. They vary in their responses to diverse foreign toxicants. Their ecological positions at the base of most aquatic food webs and their essential roles in nutrient cycling and oxygen production are critical to many aquatic ecosystems [37]. Zhu et al. [38] have studied toxicity of particles of $\mathrm{ZnO}(20$ $\mathrm{nm}), \mathrm{TiO}_{2}(<20 \mathrm{~nm})$ and $\mathrm{Al}_{2} \mathrm{O}_{3}(80 \mathrm{~nm})$ on green alga Scenedesmus obliquus and the aquatic invertebrate Daphnia magna and ranked them based on their toxicity as $\mathrm{ZnO}>\mathrm{TiO}_{2}>\mathrm{Al}_{2} \mathrm{O}_{3}$. Only a few reports are available on the effect of nanoparticles on unicellular green algae [39-41].

\section{Conclusion}

Algae constitute an important component of our environment and ecosystem as primary producer, contributing to nearly $40 \%$ of the global productivity of biomass. Observed toxic attributes of nanosilver on growth of aquatic photosynthetic algae are, therefore, matter of serious concern. On the other hand, nanoparticles can be employed for well-being of mankind by regulating algal growth and mitigating problems posed by the nuisance algal weeds in the water bodies. Pithophora and Chara have worldwide distribution and thrive in shallow ponds, lakes, water channels and reservoirs. Dense and prolific growth of these algae often interferes with fishing, irrigation, recreation, municipal water supply and other utilization of the water bodies. Pithophora is particularly recognized as one of the most difficult and persistent species of aquatic vegetation that behaves as noxious aquatic algal weed, often clog- 
ging the municipal water supply and water channels. Massive growth of charophytes in the water bodies, too, hinders the flow of water, creates problem in boating and fouls water to make it unpotable. Thus, anti-algal attributes of nanosilver can be developed as a bioengineering strategy to control unwanted algal growth and weeds, while protecting aquatic ecosystem from exposure to nanoparticles at large.

\section{Acknowledgements}

This work was supported by grants received by Anjali Dash from DST Women Scientist Scheme (DST WOSA) and by D. Dash from the Department of Biotechnology (DBT), Govt. of India, and the Indian Council of Medical Research (ICMR).

\section{References}

[1] V. L. Colvin, Nat. Biotechnol. 21, 1166 (2003). http://dx.doi.org/10.1038/nbt875

[2] R. F. Service, Science 322, 1779 (2008). http://dx. doi.org/10.1126/science.322.5909.1779a

[3] D. Y. Lee, C. Fortin and P. G. C. Campbell, Aquat. Toxicol. 75, 127 (2005). http://dx.doi.org/10.1016/ j.aquatox. 2005.06.011

[4] S. A. Masurkar, P. R. Chaudhari, V. B. Shidore and S. P. Kamble, Nano-Micro Lett. 3, 189 (2011). http:// dx.doi.org/10.3786/nml.v3i3.p189-194

[5] S. K. R. Namasivayam, K. E. Gnanendra and R. Reepika, Nano-Micro Lett. 2, 160 (2010). http://dx. doi.org/10.5101/nml.v2i3.p160-163

[6] P. R. Chaudhari, S. A. Masurkar, V. B. Shidore and S. P. Kamble, Nano-Micro Lett. 4, 34 (2012). http:// dx.doi.org/10.3786/nml . v4i1.p34-39

[7] J. R. Morones, J. L. Elechiguerra, A. Camacho, K. Holt, J. B. Kouri, J. T. Ramirez and M. J. Yacaman, Nanotechnology 16, 2346 (2005). http://dx.doi.org/ 10.1088/0957-4484/16/10/059

[8] M. Raffi, F. Hussain, T. M. Bhatti, J. I. Akhter, A. Hameed and M. Hasan, J. Mater. Sci. Technol 24, 192 (2008).

[9] S. Shrivastava, T. Bera, A. Roy, G. Singh, P. Ramachandrarao and D. Dash, Nanotechnology 18, 225103 (2007). http://dx.doi.org/10.1088/ 0957-4484/18/22/225103

[10] K. J. Kim, W. S. Sung, B. K. Suh, S. K. Moon, J. S. Choi, J. G. Kim and D. G. Lee, Biometals 22, 235 (2009). http://dx.doi.org/10.1007/ s10534-008-9159-2

[11] S. Shrivastava, T. Bera, S. K. Singh, G. Singh, P. Ramachandrarao and D. Dash, ACS Nano 3, 1357 (2009). http://dx.doi.org/10.1021/nn900277t

[12] E. Navarro, F. Piccapietra, B. Wagner, F. Marconi, R. Kaegi and N. Odzak, Environ. Sci. Technol. 42, 8959 (2008). http://dx.doi.org/10.1021/es801785m
[13] A. J. Miao, K. A. Schwehr, C. Xu, S. J. Zhang, Z. Luo, A. Quigg and P. H. Santschi, Environ. Pollut. 157, 3034 (2009). http://dx.doi.org/10.1016/j.envpol. 2009.05.047

[14] A. Saison, F. Perreault, J. C. Daigle, C. Fortin, J. Claverie, M. Morin and R. Povoic, Aquatic Toxicol. 96, 109 (2010). http://dx.doi.org/10.1016/j. aquatox. 2009.10.002

[15] N. M. Franklin, N. J. Rogers, S. C. Apte, G. E. Batley, G. E. Gadd and P. S. Casey, Environ. Sci. Technol. 41, 8484 (2007).http://dx.doi.org/10.1021/es071445r

[16] E. G. Pringsheim, J. Ecol. 33, 193 (1946). http://dx. doi.org/10.2307/2256465

[17] H. C. Bold, Bot. Rev. 8, 69 (1942).http://dx.doi. org/10.1007/BF02879474

[18] S. K. Singh, S. Shrivastava, M. K. Nayak. A. S. K. Sinha, M. Jagannadham and D. Dash, J. Bionanosci. 3, 88 (2009). http://dx.doi.org/10.1166/jbns. 2009. 1012

[19] I. Sondi and S. B. Sondi, J. Colloid. Interf. Sci. 275, 177 (2004). http://dx.doi.org/10.1016/j. jcis. 2004.02.012

[20] D. I. Arnon, Plant Physiol. 24, 1 (1949). http://dx. doi.org/10.1104/pp.24.1.1

[21] M. B. E. Godward, Nature 161, 203 (1948). http:// dx.doi.org/10.1038/161203a0

[22] M. Kumari, A. Mukherjee and N. Chandrasekaran, Sci. Total Environ. 407, 5243 (2009). http://dx.doi.org/ 10.1016/j.scitotenv . 2009.06.024

[23] P. V. AshaRani, M. P. Hande and S. Valiyaveettil, BMC Cell Biol. 10, 65 (2009).

[24] B. Nowack and T. D. Bucheli, Environ. Pollut. 150, 5 (2007). http://dx.doi.org/10.1016/j. envpol.2007.06.006

[25] O. Raize, Y. Argaman and S. Yannai, Biotechnol. Bioeng. 87, 451 (2004). http://dx.doi.org/10.1002/ bit. 20136

[26] T. Fujino and T. Itoh, Plant Cell Physiol. 39, 1315 (1998). http://dx.doi.org/10.1093/ oxfordjournals . pcp.a029336

[27] A. Fleischer, M. A. O'Neill and R. Ehwald, Plant Physiol. 121, 829 (1999). http://dx.doi.org/10.1104/pp. 121.3 .829

[28] W. L. Zemke-White, K. D. Clements and P. J. Harris, J. Exp. Mar. Bio. Ecol. 245, 57 (2000). http://dx. doi.org/10.1016/S0022-0981 (99)00151-3

[29] E. Navarro, A. Baun, R. Behra and N. Hartmann, Ecotoxicol. 17, 372 (2008). http://dx.doi.org/10.1007/ s10646-008-0214-0

[30] W. M. Lee, Y. J. An, H. Yoon and H. S. Kweon, Environ. Toxicol. Chem. 27, 1915 (2008). http://dx.doi. org/10.1897/07-481.1

[31] V. Aruoja, H. Dubourguier, K. Kasemets and A. Kahru, Sci. Tot. Environ. 407, 1461 (2009). http:// dx.doi.org/10.1016/j.scitotenv. 2008.10.053

[32] A. Thill, O. Zeyons, O. Spalla and F. Chauvat, Environ. Sci. Technol. 40, 6151 (2006). http://dx.doi. org/10.1021/es060999b 
[33] L. Yeung, W. K. Leung, N. Yao and S. Cao, Catal. Today 143, 218 (2009). http://dx.doi.org/10.1016/ j.cattod.2008.09.036

[34] K. Adams, D. Y. Lyon and P. J. Alvarez, Water Res. 40, 3527 (2006). http://dx.doi.org/10.1016/j. watres.2006.08.004

[35] J. Ma, N. Lu, W. Qin, R. Xu, Y. Wang and X. Chen, Ecotox. Environ. Safe. 63, 268 (2006). http://dx.doi . org/10.1016/j . ecoenv . 2004.12.002

[36] C. Wei, Y. Zhang, J. Guo, B. Han, X. Yang and J. Yuan, J. Environ. Sci. 22, 155 (2010). http://dx.doi. org/10.1016/S1001-0742(09)60087-5

[37] Xiong, P. Xie, X. M. Sheng, Z. B. Wu and L. Q. Xie, Ecotox. Environ. Safe. 60, 188 (2005).
[38] X. S. Zhu, L. Zhu, S. Y. Tian, Y. P. Lang and Y. Li, Acta Ecol. Sin. 28, 3507 (2008).

[39] J. Wang, X. Zhang, Y. Chen, M. Sommerfeld and Q. $\mathrm{Hu}$, Chemosphere 73, 1121 (2008). http://dx.doi. org/10.1016/j. chemosphere. 2008.07.040

[40] W. Jiang, H. Mashayekhi and B. Xing, Environ. Pollut. 157, 1619 (2009). http://dx.doi.org/10.1016/ j.envpol.2008.12.025

[41] A. Johansen, L. A. Pedersen, A. K. Jensen, U. Karlson, M. B. Hansen, J. J. Scott-Fordsmand and A. Winding, Environ. Toxicol. Chem. 27, 1895 (2008). http://dx. doi .org/10.1897/07-375.1 